\title{
STRATEGI PETANI PADI DALAM MENGHADAPI GAGAL PANEN DI DESA JAYA MAKMUR KECAMATAN KATINGAN KUALA KABUPATEN KATINGAN
}

\author{
Strategy of Rice Farmers in Facing Harvest Failure in Jaya Makmur Village \\ Katingan Kuala District, Katingan District
}

\section{Karyadi* \\ Surya Ade Putra}

Universitas Muhammadiyah

Palangkaraya, Palangka Raya, Central

Kalimantan, Indonesia

email:

karyadi@umpalangkaraya.ac..id

\begin{abstract}
Abstrak
Penelitian ini mengenai strategi petani padi dalam menghadapi gagal panen, yang menggantungkan hidupnya pada sumber agraria pertanian dilakukan menggunakan metode penelitian kualitatif. Pemilihan metode tersebut dengan pertimbangan, metode kualitatif memiliki keunggulan yaitu karena metode kualitatif melihat proses yang terjadi di lapangan dari pada produk dari objek penelitiannya. Sebagai upaya petani dalam mempertahankan subsistensinya dalam penelitian ini menggunakan analisis data secara induktif. Untuk meneliti latar belakang fenomena yang tidak dapat diteliti dengan menggunakan penelitian kuantitatif, untuk meneliti sesuatu secara mendalam dan latar belakang misalnya tentang motivasi, peranan, sikap dan persepsi dimanfaatkan peneliti yang ingin dilihat sesuatu dari segi prosesnya.

Berdasarkan hasil penelitian, bahwa strategi penelitian yang dilakukan oleh petani padi di Desa Jaya Makmur yaitu : I. Strategi alternatif subsistensi yaitu melakukan alternatif lain untuk memperoleh penghasilan tambahan dalam memenuhi kebutuhan hidup seperti: berkebun, nelayan, tukang, kerajinan menjahit, menjadi buruh dan lain-lainnya, 2. Strategi mengikat sabuk lebih kencang yaitu konsep mengikat sabuk lebih kencang memiliki pengertian melakukan penghematan terhadap kebutuhan pokok dan lebih mengatur pengeluaran mereka dengan penghasilan yang mereka peroleh, 3. Stategi jaringan/relasi yaitu jaringan sosial merupakan suatu konsep dengan berinteraksi dengan orang lain dan berhubungan erat serta harmonis dengan orang lain seperti tetangga, kerabat kerja, dan keluarga.
\end{abstract}

Kata Kunci:

Strategi

Petani Padi

Gagal Panen

\section{Keywords:}

Strategy

Rice Farmers

Failure to Harvest.

\section{Accepted}

Januari 2015

\section{Published}

April 2015

\begin{abstract}
This research is about the strategy of rice farmers in facing crop failure, which depends on agrarian sources for agriculture to be carried out using qualitative research methods. Selection of these methods with consideration, qualitative methods have advantages, namely because qualitative methods see the processes that occur in the field rather than the products of the object of research. As an effort of farmers to maintain their subsistence in this study using inductive data analysis. To examine the background of phenomena that cannot be investigated using quantitative research, to examine something in depth and background for example about motivation, roles, attitudes and perceptions used by researchers who want to be seen in terms of the process.

Based on the results of the study, the research strategies carried out by rice farmers in Jaya Makmur Village are I. Subsistence alternative strategies, namely to make other alternatives to obtain additional income in fulfilling living needs such as gardening, fishing, carpenters, sewing crafts, laborers and others other, 2. The strategy of tying the belt tighter is the concept of tying the belt tighter has the understanding of saving on basic needs and more regulating their expenses with the income they earn, 3. Network/relationship strategy that is social network is a concept by interacting with people others and are closely related and harmonious with other people such as neighbors, work relatives, and family.
\end{abstract}

\section{PENDAHULUAN}

Kondisi pertanian di Indonesia, kini terasa cukup memprihatinkan. Di mana Indonesia yang dikenal sebagai negara agraris (negara yang maju pertaniannya), sekarang malah mengimpor makanan pokoknya dari negara lain. Padahal sebenarnya rakyat dan bumi kita yang tercinta ini masih dapat memenuhi kebutuhan beras untuk makan kita sehari-hari. Indonesia adalah negara produsen beras ketiga dunia setelah China dan India. Kontribusi Indonesia terhadap produksi beras 
dunia kira-kira sebesar 8,5\% (5I juta ton). Produksi beras Indonesia yang begitu tinggi tersebut belum bisa mencukupi kebutuhan penduduknya.

Kabupaten Katingan merupakan wilayah pertanian subsisten yaitu pertanian swasembada (self-sufficiency) di mana petani fokus pada usaha membudidayakan bahan pangan dalam jumlah yang cukup untuk petani dan keluarganya. Ciri khas pertanian subsisten di Desa Jaya Makmur memiliki berbagai variasi tanaman dan hewan ternak untuk dimakan. Sehingga petani selalu memfokuskan diri pada pertanian khususnya tanaman padi sebagai kebutuhan pangan untuk mencukupi daerah sendiri. Dengan ketersediaan lahan yang luas, dan irigasi memadai, petani di Desa Jaya Makmur mampu mengembang kan lahan pertaniannya lebih efektif. Serta ketergantungan pasokan pangan dari daerah lain bisa dikurangi.

Meski dikatakan mengutamakan swasembada diri sendiri dan keluarga, petani di Desa Jaya Makmur juga memperdagangkan hasil pertanian mereka (secara barter maupun uang) demi barang-barang yang tidak terlalu berpengaruh bagi kelangsungan hidup mereka dan yang tidak bisa dihasilkan di lahan.

Kondisi petani di Desa Jaya Makmur merupakan petani yang memiliki kemampuan untuk dapat bertahan hidup dengan pendapatan yang minim dan kebutuhan subsistensi pas-pasan. Bagi petani di Desa Jaya Makmur dapat memenuhi kebutuhan hidup sudah mencukupi, walaupun dengan perolehan yang dapat dikatakan cukup bagi keluarga petani.

Sistem penanaman yang digunakan adalah sistem pananaman tunggal atau monokultur adalah salah satu cara budidaya di lahan pertanian dengan menanam satu jenis tanaman pada satu areal. Sistem penanaman monokultur dilakukan karena sebagian besar petani di Desa Jaya Makmur masih bergantung pada air sungai untuk mengairi sawahnya dengan luas lahan 745 hektar. Lahan yang digunakan oleh petani Desa Jaya Makmur dengan luas 595 hektar dan sisa dari lahan pertanian digunakan petani dari luar desa. Pertanian di Desa Jaya Makmur pada tahun 2016 membentuk sebuah kelompok tani dalam 23 kelompok dengan masing-masing kelompok terdiri dari 25 orang dengan lahan I hektare per/orang. Dengan jumlah penduduk 586 jiwa dan terdiri dari 7 Rukun Tetangga dengan masyarakat berprofesi sebagai petani.

Masalah produksi dan pasca produksi serta bergantung pada tengkulak untuk menjual hasil panennya. Selain itu infrastruktur sarana dan prasana masih kurang, jauh dari keadaan pasar, ketergantungan petani terhadap sumberdaya pertanian membuat petani enggan mencari pekerjaan yang lain yang lebih memiliki keuntungan yang lebih, petani menganggap dengan bekerja serabutan seperti nelayan, berkebun, berternak dan lain sebagainya sambil menunggu panen tiba petani dapat memanfaatkankan apa yang ada di depan mereka yang dapat di kerjakan dan menghasilkan uang walaupun pendapatan tersebut hanya cukup untuk makan dan sehari-hari keluarga petani.

\section{Strategi Bertahan Hidup}

Menurut Snel dan Staring (Setia, 2005:6) yang menyatakan strategi bertahan hidup sebagai rangkaian tindakan yang dipilih secara standar oleh individu dan rumah tangga yang miskin secara sosial ekonomi. Petani merupakan pekerja yang tekun dan tidak pernah menyerah dalam kondisi apapun walaupun penuh keterbatasan, mereka tetap bisa bertahan hidup. Petani akan mengoptimalkan segala sumber daya yang mereka miliki agar tetap bisa menjaga kelangsungan hidup keluarganya.

\section{Strategi Aktif}

Strategi aktif merupakan strategi bertahan hidup yang dilakukan dengan cara memanfaatkan segala potensi yang dimiliki. Menurut Andrianti (Kusnadi, 2000:192) salah satu strategi yang digunakan oleh rumah tangga untuk mengatasi kesulitan ekonomi adalah dengan mendorong para isteri untuk ikut mencari nafkah. Bagi masyarakat yang tegolong miskin 
mencari nafkah bukan hanya menjadi tanggungjawab suami semata tetapi menjadi tanggungjawab semua anggota keluarga sehingga pada keluarga yang tergolong miskin isteri juga ikut bekerja demi membantu menambah penghasilan dan mencukupi kebutuhan keluarganya.

\section{Strategi Pasif}

Menurut Kusnadi (2000:8) strategi pasif adalah strategi dimana individu berusaha meminimalisir pengeluaran uang, strategi ini merupakan salah satu cara masyarakat miskin untuk bertahan hidup.

Pola hidup hemat dilakukan petani kecil agar penghasilan yang mereka terima bisa untuk mencukupi kebutuhan pokok keluarga mereka. Berdasarkan uraian di atas dapat disimpulkan bahwa yang dimaksud strategi pasif adalah strategi bertahan hidup yang dilakukan dengan cara selektif, tidak boros dalam mengatur pengeluaran keluarga

\section{Strategi Jaringan}

Menurut Kusnadi (2000:146) strategi jaringan terjadi akibat adanya interaksi sosial yang terjadi dalam masyarakat, jaringan sosial dapat membantu keluarga miskin ketika membutuhkan uang secara mendesak. Secara umum strategi jaringan sering dilakukan oleh masyarakat pedesaan yang tergolong miskin adalah dengan meminta bantuan pada kerabat atau tetangga dengan cara meminjam uang.

\section{Norma Subsistensi}

Scott, 1976:19 mengatakan bahwa agar bisa bertahan sebagai satu unit, maka keluarga itu pertama dilakukan adalah harus memenuhi kebutuhannya sebagai konsumen subsistensi yang boleh dikata kan tak dapat dikurangi lagi dan tergantung kepada besar kecilnya keluarga itu. Memenuhi kebutuhan manusiawi yang minimum itu dengan cara yang dapat diandalkan dan mantap merupakan kriterium sentral yang menjalin soal-soal seperti memilih bibit, teknik bercocok tanam, penentuan waktu, rotasi tanam dan sebagainya.

Scott (1976:21) juga menyatakan bahwa untuk menjamin bagi diri mereka satu subsistensi pokok, satu orientasi yang tidak bisa tidak harus memusatkan segenap perhatian kepada kebutuhan hari ini saja tanpa memikirkan hari esok, maka petani kadang-kadang terpaksa harus menggadai kan masa depannya sendiri.

\section{Norma Resiprositas}

Ciri khas "Desa" dan ikatan "Patron-Klien" sebagai institusi kunci yang berperan dalam menjamin terpenuhnya kebutuhan-kebutuhan anggota komunitas. Resiprositas antar-kawan dan ke desa maka kita beralih ke unit-unit sosial yang dapat menguasai lebih banyak sumberdaya subsistensi dibandingkan dengan sanak saudara, akan tetapi masih merupakan bagian dari dunia intim kaum tani di mana nilai-nilai bersama dan kontrol-kontrol sosial bersama-sama memperkukuh semangat gotong-royong.

\section{Distribusi Risiko Dalam Masyarakat Petani}

Aksioma dahulukan selamat, yang merupakan konsekuensi logis dari ketergantungan ekologis mata pencaharian petani, mengandung preferensi relative bagi kepastian subsistensi di atas penghasilanrata-rata yang tinggi. Tidak saja kesadaran akan kepastian itu dalam arti ekonomis abstrak masuk akal akan tetapi, kesadaran itu dalam kenyataannya diungkapkan dalam bentuk aneka-ragam pilihan, lembaga, dan nilai dalam masyarakat petani.

\section{Kerangka Pemikiran}

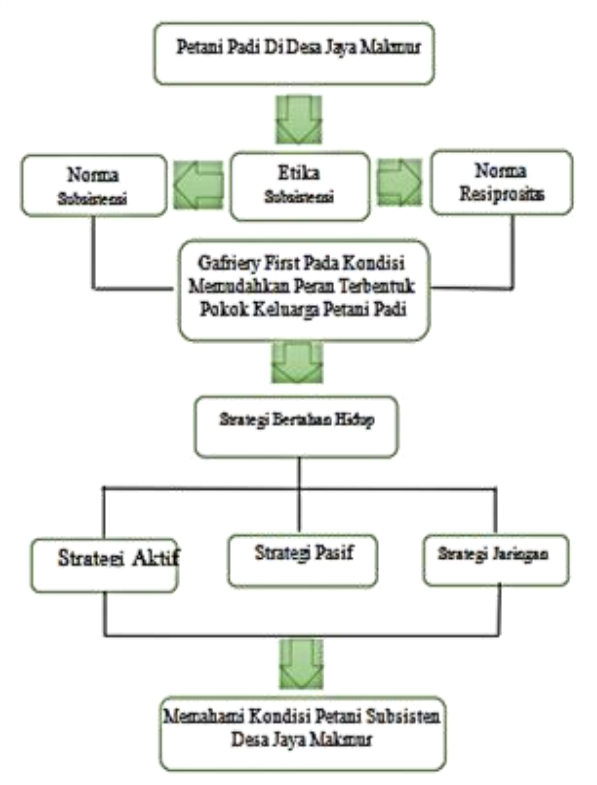




\section{METODOLOGI}

Penelitian ini menggunakan metode penelitian kualitatif. Pemilihan metode tersebut dengan pertimbangan, metode kualitatif memiliki keunggulan yaitu karena metode kualitatif melihat proses yang terjadi di lapangan dari pada produk dari objek penelitiannya. Sebagai upaya petani dalam mempertahankan subsistensinya dalam penelitian ini menggunakan analisis data secara induktif. Dalam pengumpulan datanya, peneliti menggunakan observasi langsung, wawancara mendalam, FGD dan dokumentasi.

\section{HASIL DAN PEMBAHASAN}

Berdasarkan hasil penelitian di Desa Jaya Makmur bahwa masyarakat petani padi sangat menggantungkan hidup nya pada sektor pertanian padi, dan upaya petani dalam menghadapi kegagalan panen pada merupakan keluhan petani dalam mempertahankan subsistensinya.

Petani di Desa Jaya Makmur memiliki potensi tersedianya lahan yang cukup dan hasil pertanian yang melimpah. Namun dari kegagalan panen membuat petani kesulitan untuk memenuhi kebutuhan subsistennya.Upaya Petani Dalam Mengatasi Masalah Problematika Masyarakat Dengan Hidup Dibawah Batas Subsistensi yaitu

I. Mempertahankan subsistennya dengan usaha sampingan, seperti: Berkebun, Nelayan, Berdagang, Buruh, dan lain-lainnya. Hal tersebut dilakukan Petani di Desa Jaya Makmur demi kelangsung an hidupnya dan keluarganya.

2. Mempertahankan hidup dengan cara menanam kembali lahan yang kosong dan memberi racun tikus dan pestisida agar tidak merusak tanaman padi kembali.

3. Mempertahankan hidupnya dengan cara memanfaatkan apa yang bisa mereka manfaatkan dan apa yang bisa mereka gunakan, terpenting kebutuhan subsistennya terpenuhi. Seperti menjadi buruh demi memperoleh uang. Dan memperdagangkan hasil kebun dan hasil tangkap ikan kepada penampung yang mau membeli hasil perolehan mereka.

4. Upaya untuk membantu petani dalam menghadapi permasalahan kesulitan memperoleh prasarana dan sarana produksi, kepastian usaha, risiko harga, kegagalan panen, praktik ekonomi biaya tinggi dan perubahan iklim. Serta Pemberdayaan petani merupakan upaya meningkatkan kemampuan bagi petani untuk melaksanakan usaha yang lebih baik melalui pendidikan, pelatihan, penyuluhan/pendampingan.

Faktor-faktor Penghambat Dari Kegagalan Panen adalah serangan hama, perubahan cuaca yang tidak menentu, bencana alam, mahalnya harga pupuk, kurangnya modal, kurangnya sarana dan prasarana pemasaran, keterbatasan informasi, lemah tingkat teknologi, Masalah transformasi dan komunikasi, dan Luasan usaha yang tidak menguntungkan bagi petani yang hanya dapat memenuhi kebutuhan subsistennya.

\section{KESIMPULAN}

Berdasarkan hasil penelitian Strategi yang digunakan Petani dalam mengatasi gagal panen pada tahun selanjutnya yaitu dengan :

I. Strategi alternatif subsistensi yaitu melakukan alternatif lain untuk memperoleh penghasilan tambahan dalam memenuhi kebutuhan hidup seperti: berkebun, nelayan, tukang, kerajinan menjahit, menjadi buruh dan lain-lainnya. Hal itu dilakukan petani untuk bertahan hidup dan sanggup mengorbankan dirinya dan jasanya untuk memenuhi kebutuhan subsistensi nya, yang terpenting kebutuhan ia dan keluarganya tidak kelaparan.

2. Strategi mengikat sabuk lebih kencang yaitu konsep mengikat sabuk lebih kencang memiliki pengertian unutk melakukan penghematan 
terhadap kebutuhan pokok dan lebih mengatur pengeluaran mereka dengan penghasilan yang mereka peroleh.

3. Stategi jaringan/relasi yaitu jaringan sosial merupakan suatu konsep dengan berinteraksi dengan orang lain dan berhubungan erat serta harmonis dengan orang lain seperti tetangga, kerabat kerja, dan keluarga. Jaringan sosial ini dapat membantu keluarga yang mengalami kesulitan, baik dari pinjaman uang maupun tenaga kerja yang mereka miliki. $\mathrm{Hal}$ itu dapat mepermudah kesulitannya selama dalam permasalahan untuk memenuhi kebutuhan subsistensinya.

\section{REFERENSI}

Kusnandi. 2000. Nelayan Adaptasi dan Jaringan Sosial. Bandung : Humaniora Utama Press.

Namawi, Handari. 2005. Manajemen Strategik Organisasi Non Profit Bidang Pemerintahan. Yogyakarta: Gajah Mada University Press.

Pakpahan, A. 2004. Petani Menggugat. Max Havelaar Indonesia Foundation, Jakarta.

Salusu, J. 2003. Pengambilan Keputusan Strategik untuk Organisasi Publik dan Organisasi Non Profit. Jakarta: PT. Gramedia Widia Sarana Indonesia.

Setia,R. 2005. Gali Tutup Lobang Itu Biasa Strategi buruh Menanggulangi Persoalan Dari Wakti ke Waktu. Bandung: Yayasan Akatiga.

Sugiyono. 2007. Metodologi Penelitian Kualitatif. Bandung : PT Remaja Rosdakarya.

Scott, C James. 1976. Moral Ekonomi Petani. Pergolakan dan Subsistensi Di Asia Tenggara. LP3ES 